\title{
AN UNKNOWN HEBREW MEDICAL ALCHEMIST: A MEDIEVAL TREATISE ON THE QUINTA ESSENTIA
}

\author{
by
}

RAPHAEL PATAI*

\section{INTRODUCTION}

AMONG the many Latin writings published under the name of Ramón Lull (c. 1235-c. 1316), the famous Majorcan Christian mystic, philosopher, and missionary, styled doctor illuminatus and sacer doctor, there are several that deal with the fabulous quinta essentia, the purest of essences, which was supposed to have the power to rejuvenate the old and to cure all kinds of diseases, including mental aberrations. The popularity of Lull is attested, among other things, by the fact that one of these books, entitled De secretis naturae sive quinta essentia (On the secrets of nature or the fifth essence, hereinafter De secr.), was reprinted at least eight times between 1514 and 1557.' Another Lullian work on the quinta essentia, Libellus Raimundi Lullii maioricani de medicinis secretissimis (The Majorcan Raimund Lull's book on the most secret medicines, hereinafter De med.), is contained in a collection of Lullian writings entitled Raimundi Lullii Maioricani philosophi sui temporis doctissimi libelli aliquot chemici (Some chemical writings of the Majorcan Raimund Lull, the most learned philosopher of his time). ${ }^{2}$ Lullian treatises on the quinta essentia continued to appear even in the seventeenth century. ${ }^{3}$

All who studied the Lullian corpus agreed that such alchemical treatises attributed to him could not have been written by Lull, who was not an alchemist and who, in his authentic works, expressed himself about alchemy in unmistakably negative terms. The conclusion that the De secr. was falsely attributed to Lull was reached as early as the late seventeenth or early eighteenth century by the authors of the Acta sanctorum, who observed that Lull himself often rejected alchemy (chimia) and denied that the alchemists could make gold.' This conclusion leaves wide open the question of the actual authorship of the De secr. It has been suggested that it was written by another Ramón, a certain Ramón de Tárraga, who was born to Jewish parents about the time Lull died, and who, after reaching manhood and becoming a rabbi, converted to

\footnotetext{
* Raphael Patai, PhD, 39 Bow Street, Forest Hills, NY 11375, USA.

${ }^{1}$ No less than seven of these editions (Venice, 1514; Augsburg, 1518; Venice, 1521; Lyons, 1535; Venice, 1542; Nuremberg, 1546; Venice, 1557) are found in the National Library of Medicine, Bethesda, Maryland. A copy of the Strasbourg, 1541, edition is found in the Engineering Library, New York.

2 Printed in Basle, 1600, pp. 330-374.

${ }^{3}$ E.g., Raymundi Lullii Tractatus brevis et eruditus de conservatione vitae: item Liber Secretorum sive quintae essentiae .... Strasbourg, 1616.

4 Cf. Erhard-Wolfram Platzeck (editor), Raimund Lull, Opuscula, 3 vols., Hildesheim, H. A. Gerstenberg, 1971-73, I:xviii; II:xlvii.

SActa sanctorum, June vol. 5. Antwerp, Apud Viduam Petri Jacobs, 1709, pp. 657-661, 706.
} 


\section{An unknown Hebrew medical alchemist}

Christianity. ${ }^{6}$ De secr. was certainly available to Johannes de Rupescissa in the latter part of the fourteenth century, for his book De consideratione quintae essentiae rerum omnium (On the consideration of the fifth essence of all things) relied heavily upon it. ${ }^{7}$ Although my own perusal of contemporary papal and other documents leads me to accept Ramón de Tárraga as the author of De secr., for the sake of brevity I shall hereinafter refer to both De secr. and De med. as "Lullian" works.

Lullian authorship is claimed for a brief Hebrew manuscript in the Bibliothèque Nationale, Paris, (fonds hébr. 1207, fols. 155 verso-1 58 verso). The MS also contains chapters 3 to 7 of the Canon of Avicenna, written in Arabic in Hebrew characters. This MS was known to Steinschneider, who devoted almost two pages to its discussion in his classic book on medieval Hebrew translations. ${ }^{8}$ Strangely, however, apart from copying the name Raimon incorrectly as Romon, Steinschneider said nothing about the Hebrew MS itself, and instead discussed in some detail the De secr., which, he suspected, was its source. He compared the various sixteenth-century editions of De secr., and wondered "whether the Hebrew reviser read humanum (human) after the word coelum (heaven)", since the term "human heaven", used by the Hebrew author as the designation for the quinta essentia, does not occur in De secr., which instead uses consistently the term coelum nostrum (our heaven) as the designation for the quinta essentia. ${ }^{9}$ Rupescissa, on the other hand, often called the quinta essentia by the name coelum humanum (see below), and the author of the Hebrew MS could have borrowed the term from him.

Even a cursory comparison of the Hebrew MS with De secr. shows that the former is neither a translation of the latter, nor a summary of its contents, nor a reworking of it. Nor does it have any such relationship to De med. In fact, not a single paragraph or sentence contained in either Lullian treatise reappears in our MS. While all three works deal in the main with the quinta essentia, the contents of each are different.

The Hebrew MS differs from the other two even in structure. It begins with the words, "And now I shall copy for you a great secret of the Fifth Essence ... it was written by a great sage whose name is Raimon, and he placed introductions in front of it, and they are these...". It was this prefatory sentence that misled Steinschneider, who evidently did not examine the whole MS, to state that it was a reworking of De secr. The anonymous author of the Hebrew MS seems to have claimed Lullian

\footnotetext{
- Johann Albert Fabricius, Historiae Bibliothecae Fabriciana Pars V, Hamburg 1722, p. 526; idem, Bibliotheca Latina mediae et infimae Aetatis. Hamburg, 1735, vol. IV, p. 863; José Ramón de Luanco, Ramón Lull (Raimund Lulio) cosiderado como Alquimista, Barcelona, 1870; John Ferguson, Bibliotheca chemica, Glasgow, 1906, vol. 2, p. 54; Arthur Edward Waite, Three famous alchemists, Philadelphia, David McKay [c. 1903], pp. 59-60; Lynn Thorndike, A history of magic and experimental science, New York and London, Columbia University Press, 1923, 2:864, 867; A. E. Waite, The secret tradition of alchemy, London, Kegan Paul; and New York, Knopf, 1926, p. xviii. Cf. also Léopold Delisle, in Histoire de la France, vol. xxix (1885), who states on p. 282 that De secr. is a forgery ("faussaire").

' Rupescissa wrote most of his works while imprisoned in Avignon by Pope Innocent VI (r. 1352-62). He seems to have been burned at the stake in 1362. The Lullian alchemical treatises were burned in 1372 at the order of Pope Gregory XI. The Allgemeines Gelehrten-Lexicon, vol. 3, Leipzig, 1752, pp. 2315-2316 states that Rupescissa's De consideratione (printed in Basle, 1597) "was almost entirely copied from Raymun Lull."

- Moritz Steinschneider, Die hebräischen Übersetzungen des Mittelalters und die Juden als Dolmetscher. Berlin, 1893 (photographic reprint, Graz, Akademische Druck-und Verlagsanstalt, 1956), pp. 824-825.

E.g., fols. 18v, 20v, 21r, 22v, 23r, 32v, 34v, 37r, 37v, etc.
} 


\section{Raphael Patai}

authorship for his brief treatise for the same reason that motivated Ramón de Tárraga (if, indeed, he was the author of De secr.) to attribute his to Ramón Lull: the desire to endow his book with the prestige and respect commanded by Lull in the fourteenth century among the philosophers, theologians, and physicians of Spain.

The spuriousness of this Lullian claim becomes evident immediately after the two prefatory sentences. Contrary to the Hebrew author's statement that "Raimon" wrote "introductions" to his work on the quinta essentia, which he purports to "copy", i.e. translate, neither the De secr. nor the De med. contains any introduction. The seven brief introductions with which the Hebrew MS opens are definitely original to the Hebrew author, who summarizes in them his views on the origin of diseases, the harmful effect of fear, and the nature of the quinta essentia. Echoing a statement by Rupescissa to the effect that "This Fifth Essence is the human heaven which the Most High created for the conservation of the four qualities of the human body, just as [he created] the heaven for the conservation of the whole universe", ${ }^{10}$ our author amplifies it and presents in some detail the similarity between heaven and the quinta essentia, "the human heaven"."

The conclusion that our author did not intend to summarize, let alone translate, the De secr., the De medij or Rupescissa's book on the quinta essentia is further borne out by his text. Thus, for example, where the two Lullian works give long lists of the materials from which the quinta essentia can be produced, arranging them in groups of minerals, animals, herbs, roots, fungi, etc., and proceed to describe "the mode of the preparation of the quinta essentia from gold" and its composition, of all this there is no trace in the Hebrew MS, whose author, evidently, was not interested in such details. Instead, he states briefly in his Sixth Introduction that the fifth essence can be distilled "from the edibles, such as meat or fruit or herbs ...".12

The next part of the Hebrew MS, which deals with the diseases that can be cured by an admixture of the fifth essence into specific medicines or drugs, shows a certain similarity to the Lullian works. This was inevitable, since they were all intended to serve as medical guides, and therefore had to specify such diseases as were recognized and diagnosed in their time, and their cures. Yet here, too, the differences are greater than the similarities. Where Lull groups the diseases into sixty-one "canons" (of which forty-four are contained in the first book, and seventeen in the second, of $D e$ secr.), the Hebrew author treats them under nineteen "benefits". Neither are the actual treatments prescribed identical, or even similar. For instance, in discussing the cures against poisons, both De secr. and De med. enumerate the venomous animals, while the Hebrew MS does not. In addition, while the two Lullian works rely primarily on the effect of "the fifth essence of things" in curing poisonings, the Hebrew MS recommends the fifth essence mainly as a solvent for "antidotes of poison" whose identity it does not specify, probably because it assumes that they were well known to its readers. Another important difference is that the Hebrew author

\footnotetext{
${ }^{10}$ Rupescissa, De consideratione quintae essentiae rerum omnium, p. 18. My translation from the Latin, which reads: "Haec quinta essentia est coelum humanum quod creavit Altissimus ad conservationem quatuor qualitatum corporis humani, sicut coelum ad conservationem totius universi." On the same page, Rupescissa refers to "quinta essentia id est coelum humanum".

11 Fol. 155v.

12 Fol. 156r.
} 


\section{An unknown Hebrew medical alchemist}

recommends the use of an emetic, while the Lullian treatises prefer purgatives and external applications. It may be of interest that Maimonides (1135-1204), in his book on poisons and their antidotes (which our author may have known), recommended all the three types of therapy: emetics, purgatives, and external treatments. ${ }^{13}$

As for the identity of the author, all that can be said is that he was a Jewish physician who lived in Spain in the fourteenth or fifteenth century, and knew, in addition to Hebrew, Latin, Spanish, Arabic, Persian, Turkish, and Sanskrit.

Was our author an alchemist? He undoubtedly was influenced by the alchemical teachings of his time, in which the quinta essentia occupied a prominent place. $\mathrm{He}$ repeats again and again that the admixture of the quinta essentia will increase the effectiveness of drugs. Like Lull, he considers that the quinta essentia can cure almost anything, from melancholy to pestilential fever, and from poisoning to demoniac possession; it can remove any foreign object, such as arrow or thorn, which penetrates the body; it can even rejuvenate old men, renew the spirit of life, and endow women with beauty. Yet, despite these clearly alchemical features, one gains the impression that the author relies more on the curative powers of the drugs themselves than on that of the quinta essentia added to them. Nowhere does he recommend the application of the quinta essentia by itself; he always suggests its use as an agent intensifying or augmenting the curative properties of drugs. Hence, one is led to the conclusion that he was primarily a physician, and only in the second place an alchemist.

In the translation that follows I have retained all non-Hebrew terms (medical, botanical, etc.) in the form in which they appear in the text, rendering them in a phonetic transliteration. The Arabic paragraph inserted into folio $157 \mathrm{v}$ has been translated freely into English, since its syntax is extremely problematic. The footnotes appended to the text contain translations or explanations of the Hebrew, Spanish, Latin, Greek, Arabic, Persian, Turkish, and Sanskrit terms used by our author, and references to other medieval Hebrew medical texts, to the appearance of corresponding terms in the Lullian works, and to the use in folk-medicine of the materia medica mentioned in the text.

\section{ACKNOWLEDGEMENTS}

In deciphering and identifying some of the terms I was helped by Dr Houssam Khalil and Dr Shubhra Basu of the Oriental Division of the New York Public Library, Prof. Alex Wayman of Columbia University, and Profs. F. Marquez and Maria Esformes of Harvard University, to all of whom I express my thanks. I also wish to thank the Jewish and Oriental Divisions of the New York Public Library, the Engineering Library, and the Library of the New York Academy of Medicine in New York City; the Hebraic Section of the Library of Congress in Washington and its head, Mr Myron M. Weinstein; and the National Library of Medicine in Bethesda, Maryland, and its curator of rare books, Dr Peter Krivatsy; without whose resources this study could not have been written. My special thanks are due to the Bibliothèque Nationale, Paris, for permission to publish a translation of this MS, and to Miss Madeleine Neige, head of its Service Hébraique, for her help.

${ }^{13}$ Süssman Muntner, Moshe ben Maimon (Maimonides), Poisons and their antidotes, Jerusalem, Rubin Mass, 1942, pp. 98ff. 


\section{Raphael Patai}

\section{TRANSLATION}

[Folio 155v] And now I shall begin, with the help of God, to copy for you a great secret of the fifth essence, which is called in their language ${ }^{1}$ qinta esensia. It was written by a great sage whose name is Raimon, and he placed introductions in front of it, and they are these:

The first introduction. The diseases come because of a lack of the natural strength, and the medicine which is capable of restoring health must be one which is not subject to putrefaction, ${ }^{2}$ and is capable of renewing the spirit of life which has been lost, and of adding the radical humidity and strengthening the natural heat which has become weak.

The second introduction. Every thing which is affected by fear is sick and weak, and if the afflicted [person] is given a thing which is affected by fear he will become more afflicted. And since the physicians act against all the things, they will harm, and afflict, and kill. And it also happens to those who cannot comprehend this secret which the physicists ${ }^{3}$ have comprehended. Therefore it is proper to search and to seek a thing in which are found the four qualities which are in us, and the four materiae of which our bodies are composed, and this will not be subject to corruption, just as the heavens are not subject to corruption ${ }^{3 \mathrm{a}}$ in the arrangement of the four elements. And this is why the physicists called the heaven by the name Fifth Essence, because the heaven is not subject to corruption, for it is not hot as fire [and] is not a thing foreign or alien

\section{FOOTNOTES TO THE TRANSLATION}

The following abbreviations are used in the footnotes:

Ben Yehuda - Eliezer Ben Yehuda, Thesaurus totius hebraitatis, completed in 1959.

Bulcke - C. Bulcke, An English-Hindi dictionary, Ranchi, Bihar, 1968.

De med. - Raimund Lull, De medicinis secretissimis, in Raimundi Lullii Maioricani philosophi sui temporis doctissimi libelli aliquot Chemici, Basle, 1600.

De secr. - Raimund Lull, De secretis naturae sive quinta essentia, Strasbourg, 1541.

Diccionario - Diccionario historico de la lengua española, Madrid, Real Academia Española, $1964-68$.

Dubler - C. E. Dubler, La "Materia Medica" de Dioscorides. Transmisión medieval y renacentista, 6 vols., Barcelona, Tipografia Emporium, 1953-59.

Hovorka-Kronfeld - Oskar von Hovorka and Adolf Kronfeld, Vergleichende Volksmedizin, 2 vols., Stuttgart, Strecker \& Schröder, 1908-9.

Löw - Immanuel Löw, Die Flora der Juden, 4 vols., Vienna, 1923-34.

Meyerhof - Max Meyerhof, Śarh Asmā al-'Uqqăar (Explication des noms de drogues) [by Mamonides], Mémoires ... Institut de l'Egypt, vol. 41, Cairo, 1940.

Molinar - Maria Molinar, Diccionario de uso del Español, Madrid, Editorial Gredos, 1967.

Monier-Williams - Sir Monier Monier-Williams, A Sanskrit-English dictionary, Delhi, Patna, and Varanasi, Motilal Banarsidass, 1963 (repr. 1974).

Muntner, Asthma - Süssman Muntner, Moshe ben Maimon (Maimonides) The book on asthma, Jerusalem, Rubin Mass, 1940.

Muntner, Poisons - Süssman Muntner, Moshe ben Maimon (Maimonides) Poisons and their antidotes, Jerusalem, Rubin Mass, 1942.

Patai - Raphael Patai, On Jewish folklore, Detroit, Mich., Wayne State University Press, 1983.

Ruland - Martin Ruland, Lexicon Alchimiae sive Dictionarium Alchemisticum, Frankfurt am Main, 1612.

Rupescissa - Johannes de Rupescissa, De consideratione quintae essentiae rerum omnium, Basle, 1597.

Siggel - Alfred Siggel, Arabisch-Deutsches Wörterbuch der Stoffe aus den drei Naturreichen ..., (Deutsche Akademie der Wissenschaften, Berlin, Institut für Orientforschung, Veröffentlichungen, no. 1), Berlin: Akademie Verlag, 1950.

Testi - Gino Testi, Dizionario di alchimia, Rome, Casa Editrice Mediterranea, 1950.

Wahrmund - Adolf Wahrmund, Handwörterbuch der arabischen und deutschen Sprache, 2 vols., Giessen, J. Ricker, 1877.

1 "Their language" refers to Spanish. The transliteration qinta esensia shows that the author uses the Spanish form.

2 'Ippush, mouldiness, decay, putrefaction, a term often used by medieval Hebrew medical authors.

${ }^{3}$ The Hebrew Tiv iyyim, can mean naturalists or physicists, i.e., scholars who devoted themselves to the study of nature. Cf. Ben Yehuda, s.v.

3a Rupescissa, p. 16, says that the quinta essentia is "sicut coelum incorruptibile" (like heaven incorruptible). 


\section{An unknown Hebrew medical alchemist}

to the four elements. And this thing of which we speak is called Human Heaven or Fifth Essence, for it is in them, in the arrangement of the four materiae. And it is not subject to corruption for it is not hot as fire, nor humid as air, nor cold as water, nor dry as dust. And just as the heaven bestows humidity when it is needed, and heat when it is needed, and likewise coldness and dryness, so the Fifth Essence bestows upon us what is called Spirit of Life, which is composed of the four elements and is separated from them through human artifice. 4

The third introduction. It is proper that you know that our Fifth Essence is not cold, for it warms the coldness; and not hot, for it cools the heat; and not humid for it dries the humidity; and not dry for it humidifies the dryness. And it nourishes the body and protects it from all corruption and putrefaction, and thus it seems like a true marvel, for if put in a vessel and then if one puts into it a slaughtered fowl or a piece of meat, it will not putrefy as long as it is there, and then it will dry, since it has this effect [also] on a live body.

The fourth introduction. Just as the highest heaven does not on its own influence the existence of the world, but [does this] through the intermediacy of the luminaries and the stars, and through them produces enormous and awesome effects, so for our Human Heaven it is proper that it should be aided by the things which are influenced by it, such as the medicines, or the herbs which have virtues for the limb which we intend to cure. For instance, if we intend to cure the head, it is proper that we should put into our Heaven those things which help the head, and thus for the other limbs.

The fifth introduction. It is proper that you should take the water which rises from the wine in a most clear distilling vessel. And let it rise at least four times in the distilling vessel in which there should be many rising and descending tubes, for the more it rises the more it will become purified and the farther it will be from putrefaction and corruption.

And let me tell you what I heard from a man whose words are trustworthy, who saw it in the court of the king of Spain where they did it in this manner. After they made it rise in the distilling vessel four times, they hid it in horse manure in a glass vessel, tightly sealed. And after four months they took it out gently, and transferred it into another vessel, so that the sediment should not be mixed up, and they buried it for another four months. And so they did for yet another four months, until a full year. And then they took it out, and there was not found in the bottom of the vessel even the thinnest dust, so thoroughly was it purified. And its scent rose as if it had issued [folio 156r] from the Garden of Eden. And this is the proper way for you to proceed in order to achieve your desire.

The sixth introduction. Likewise it is proper to distil all things which you want to purify and to make of them the Fifth Essence: from the edibles such as meat or fruit or herbs, and mix them with the aforementioned heaven to cure with them any malady you wish.

The seventh introduction. Likewise it is proper for you, if you want to prepare a potion for a disease, to place those drugs which are appropriate for that potion into our Fifth Essence, and it will become like the potion, and it will be more effective, one part of it to a hundred. And likewise the things which constipate, or the fragrant drugs, and thus all things of this kind, and thus all the cordial drugs ${ }^{5}$ must be pounded to utter thinness, until one cannot feel it by palpation, and then they must be put into the aforementioned water. And prepare in a like manner the laxative medicines, for this water will add power of effectiveness a hundred-fold, without doubt. Also, if a man is given a deadly poison, put of the water which received the poison into the aforementioned water, and he will instantly vomit up the poison which he swallowed or imbibed. Also, in order to remove an iron arrow or any object or thorn from any place, put into the aforementioned water the things which attract. Also, in order to clean any wound, put into it the cleansing drugs. And likewise, to make flesh grow, put [into this water] the drugs which cause the flesh to grow, and likewise those drugs which constipate, and which contract, and all of them in this manner.

\footnotetext{
4 "Human artifice" is again a phrase reminiscent of Rupescissa, who says (p. 17) that the quinta essentia was created by God and can be extracted from the body of nature "cum artificio humano" (with human artifice).

s Hasamim haleviyyim, i.e., drugs pertaining to the heart.
} 


\section{Raphael Patai}

Now I shall begin to explain the virtues of the aforementioned water in their general benefit, although we have already mentioned some of them above when we spoke of their importance. However, I shall tell here a little of the secrets which no man has comprehended, except for him to whom their virtues have been revealed by word of mouth of those present. And they are powerful things for curing, with the help of the True Beneficer, all serious diseases which the physicians have despaired from curing, except those which are come by the Divine Will, decreed upon him from the allotted lifetime.

The first benefit is to restore the strength of old men which has become debilitated very much, and it will restore it, with the help of God in whose hand is the strength and the power. Take the aforementioned precious water after it has been purified most thoroughly, and add to it [of the Fifth] Essence of the gold and the crystal. Thus for the debilitated, each time half an egg full. And if the True Physician so decrees, he will be almost cured, and his strength will return to him like one of the young men, thirty years of age. And after he returns to the days of his youth he should no longer take of it.

The second benefit is to cure with it those who have been debilitated by disease to the point of a depression of the soul, except for those whom God wants to take, whose days have reached their end, or as a punishment, or, as in the case of the anointed of God, King David, peace be upon him, [who said] of Saul, "If his day comes, or if God smites him," etc. ${ }^{6}$ And this on condition that the sick person is able to drink it. And also give them of the aforementioned water for the old and debilitated, and as soon as the medicine goes down into the stomach it will endow the heart with a new spirit of life, and augment the natural heat which had diminished, and his strength will return to him as it was in the beginning. And if you want him to arise in his time and become healthy, give him the aforementioned water of the Fifth Essence which arises from the herb salidonia, ${ }^{7}$ about [as much as] a grain of wheat, and you will see a mighty miracle, as if he had never been sick, and he will walk on his staff, if the True Powerful so decrees. And this secret is of the most important secrets of nature which can be found; no physician has comprehended it in these our times.

The third benefit is that it heals leprosy, except if it is an ensnaring one, for [to heal] that is of the impossible things. And it is proper that you should know that this water, with the help of the True Helper, will cure him of the leprosy, because this medicine devours all corrupt and putrefied material, of whatever humidity it be. And I can attest to you that this [folio 156v] water, with the water of the gold and the crystal, and with even more power if one puts into it the fruit which is called in their language frasas, and in $L^{\prime} a z$ fraulas, and in Turkish jilek, ${ }^{8}$ which is a small round fruit like the grapes of the thorn bush which is called mora sarsa, ${ }^{9}$ and its leaves are like its leaves, except that they grow near the ground and they have no thorns, and their taste is sweet, leaning a little to sourness, and they have a good smell. And the aforementioned water with the aforementioned fruit strengthens nature very much, and drives away all poison and corruption and putrefaction from the human body, and brings their menses to women, and helps to pregnancy, and they are beneficial to cure the cataract in the eye. And I saw a woman in whose face the traces of leprosy were visible, and she washed in this water, and the leprosy was instantly cured.

The fourth benefit is to cure all growths or scurfs or discharge of whatever kind. Let there be

\footnotetext{
'Quotation, in a modified form, from 1 Sam. 26:10, which reads, “.. The Lord shall smite him, or his day shall come to die...".

'Salidonia, from the Latin chelidonia, celandine, swallow-wort or pilewort, a weedy plant of the poppy family.

Frasas, is Spanish fresas, strawberries. I am unable to identify fraulas or praulas. Fralles, Dubler VI 101. La'az in medieval Hebrew authors usually refers to the local colloquial, which in this case would be Spanish, but since our author calls Spanish "their tongue" (see note 1), his "la'az" seems to refer to Latin. Latin = fragulae - easily misrepresented as fraula. Jilek, is the Turkish Çilek, strawberry.

- Mora sarsa. Mora in Spanish is raspberry or blackberry. Sarsa is the Spanish zarza, common bramble, or the European blackberry, rubus fruticosus. In modern Spanish usage the name of the blackberry is zarzamora, cf. Molinar, s.v.
} 


\section{An unknown Hebrew medical alchemist}

put into the aforementioned Fifth Essence some tartaro which is called rasuras ${ }^{10}$ after having burned it to lime, and let him anoint with it the spot, and it will be cured.

The fifth benefit is to cure perlesia." If you put into this water some of those things which destroy the white [humour], ${ }^{12}$ such as farfiyun turbid, ${ }^{13}$ the husk of shawqu $u^{14}$-root, for these have the virtue of strengthening the vessels of feeling and motion, and also put on the paralyzed places a plaster of cooked and ground bazr qatuna, ${ }^{15}$ and take of it five parts, and olive oil three parts, and wax two parts, and let the patient drink of their decoction thirty consecutive days.

The sixth benefit is for the sufferers of blight which is called tisical6 and for all kinds of shrivelling. An infant or a child, or a youth, or a mature man, or an old man, whether man or woman, let there be given to them of the aforementioned water with that which comes up from the aforementioned salidonia, and they will, within a short time, return to their strength and fatness; as if they had never been sick at all.

The seventh benefit is for insanity or madness or melakhonia" or rage or spleen. Give them of the aforementioned water, with the Fifth Essence, of the gold and the crystal, with a little of the drugs which purge the sharpened black humour, ${ }^{18}$ and the seed of fuagia ${ }^{19}$ and its root.

The eighth benefit is for the weakness of the heart or fainting, or beating or fluttering, and the like. Give him the aforementioned essence of gold and crystal and the herb peonia ${ }^{20}$ and the toronjil ${ }^{1}$ which is called badrang buya ${ }^{22}$ and saffron, and he will be cured entirely with the help of God.

The ninth benefit is to cure the bewitched and those who were injured by demons or an evil spirit. [Give] the patient of the aforementioned water with the water of the gold and the crystal, and put into them the seed of perforata, ${ }^{23}$ that is, qorasonsilio, ${ }^{24}$ and he will be saved with the help of God.

The tenth benefit is against lice and the kind which is called adadores ${ }^{25}$ which come into being in the flesh between the skin and the flesh and which cause plague spots and great friction in the body. These things are born from the heat, in addition to being [born] from the putrefaction of

\footnotetext{
10 Tártaro. Spanish tartaro, explained in our text as rasuras, which in Spanish means argol, tartar in its natural form as deposited in wine casks.

"Perlesia. Spanish perlesia, muscle weakness accompanied by trembling, paralysis.

12 Hal'vana, lit. "the white one". Medieval Hebrew medical authors call by this name the phlegm, one of the four humours which, since Hippocrates and Galen, were believed to be responsible for one's health and disposition. The preponderance or impairment of any one of these humours was believed to cause certain types of diseases. Cf. Ben Yehuda, s.v.

${ }^{13}$ Farfiyun turbid. Persian farfay $\overline{u n}$ or farfiyūn, is the euphorbium or gum euphorbium, an African plant. The yellow or brownish, very acrid gum resin derived from the Euphorbia resinifera of Morocco and other African species was used medicinally as an emetic or cathartic. Also called furbiyūn or afarbiyūn in Arabic, cf. Meyerhof, p. 15, no. 25. Arabic turbid (turbidh in Avicenna), is a purgative, cf. Muntner, Asthma, p. 124, and index. Thus farfiyūn turbid is purgative euphorbia.

14 Shawqu, probably from the Arabic shawk or shawka, thorn, thistle.

is Bazr qatuna, Arabic bazr qatūna or qutna, cotton seed, Plantago psyllium L. Cf. Siggel, p. 20; Patai, pp. 347, 372.

16 Tisiqa, Spanish tisica, from the Latin phthisica, atrophy, asthma, pulmonary consumption.

17 Melakhonia, i.e., melancholy, the state of mind caused by the melan-chole, black bile, which our author terms hash'hora, the black one.

18 Hash'hora hamuhadit, acute black bile or acute melancholy.

19 Fuagia. I am unable to identify this term; perhaps phlegium (Dubler III 287).

${ }^{20}$ Peonia, Spanish peonia, peony, Cf. Hovorka-Kronfeld 1:186, 349.

${ }^{21}$ Toronjil, Spanish toronjil, from the Arabic taranjabil, genet d'Espagne, waythorn, furze broom genista, balm gentle, Melissa.

${ }^{22}$ Badrang buya, Persian badrangbuya, Melissa officinalis, mountain balm. Cf. Muntner, Poisons, p.

118; Meyerhof, p. 22, no. 40. Also called turunjān, cf. Meyerhof, p. 22, no. 40, and the preceding note.

${ }^{23}$ Perforata, a herb, perfoliate, or St John's wort, Hypericum perforatum $L$. Cf. Hovorka-Kronfeld 1:228-30. In Spanish perfoliata means hare's ear, thoroughwort-wax, bupleurum rotundifolium.

${ }^{24}$ Qorasonsolio, Spanish corazoncillo, perforated St John's wort, Hypericum perforatum.

2s Adadores, Spanish aradores, parasitic mites affecting animals and man, and causing a skin disease characterized by scabby eruptions.
} 


\section{Raphael Patai}

wetness. And if the patient washes his body with the $\ldots{ }^{26}$ of the Fifth Essence, he will be saved from the aforementioned affliction, and especially if you mix into it quicksilver and mozaj. ${ }^{27}$

The eleventh benefit is to save from all poisons or deadly drugs. Take of the aforementioned essence, and put into it of the remedies which are antidotes ${ }^{28}$ of poisons, and give them to the patient, and with the help of God he will instantly vomit out the poison which he has eaten or drunk or which has come from the outside, from [folio 157r] the bite of a poisonous animal. And if a person takes of the aforementioned things, and [thereafter] some kind of poison is given to him, it will not harm him, with the help of God.

The twelfth benefit is to cure the quartan fever ${ }^{29}$ and all the diseases which come from the black [humour] ${ }^{30}$ There are some physicians who say that there is no use in removing it quickly, but [only] in prolonging the time of its cure. And if you want to cure it quickly and easily, give the patient of the aforementioned water. And if you want to add to it some of the things which are antidotes of the black [humour], it will be more effective, on condition that he give it to the patient slowly, so that he does not weaken the nature.

The thirteenth benefit is for all those who were damaged by a laxative or emetic drug, which did not work or which worked in excess. For the laxative drugs must be viewed from three points-of-view. First, the laxative must not weaken the vital force. Second, it must not be of the sharp and deadly drugs. Third, one must try to remove from, or diminish in, that drug any sharpness or poisonousness as far as possible, And [since] the physicians cannot do this as far as possible, at times they cause damage and at times [the medicine] does not help and does not save, for the constitutions, ${ }^{30 a}$ and the years, and the time are not the same for all people and diseases. Let him put of the medicines into the aforementioned water, [and] they will act gently and without weakening the strength. Therefore it is proper that the physician should give the patient only one grain with our essence, and he will see wonders. And if he needs to give more, let him give the second time two grains, and thus gradually, according to the nature of the patient and the nature of the disease, and open your eyes and see!

The fourteenth benefit. All physicians agree that the permanent fever ${ }^{31}$ is caused by a mixture of all putrefied materials, and its cure is to empty the blood and clean it of all rust and from the mixture of bad humours which are mixed into it. This is done completely by our Fifth Essence which removes and separates from the blood all putrefied material because it differs from the four qualities, for it is neither hot nor cold, neither humid nor dry. Therefore you can give it constantly without any fear, and especially if you mix into it the essence of the gold and the crystal and the blood which were mentioned above, and if you anoint with it the temples and the neck and the veins and pulses, and the palms of the hands and the soles of the feet, and if you add to it the herb called marqurial, ${ }^{32}$ you will add a wonderful thing to its effectiveness.

The fifteenth benefit is for curing the tertiary fever. The tertiary fever is born of the red and putrefied things. ${ }^{33}$ If you want to cure it, put immediately into the [ingredients] mentioned some of the things which draw out the red [humour] and part of the cured liquid, ${ }^{34}$ and give it to the patient to drink in the evening and in the morning, and he will be cured with the help of God.

${ }^{26}$ Word illegible. Perhaps meha'alim, of the leaves.

${ }^{27}$ Muzaj. Probably Arabic mazaj or mizj, honey, bitter almond.

${ }^{28} M$ 'nagdim, lit. opposed to.

29 Haqadahat ha'd, quartan fever. Cf. Hovorka-Kronfeld 2:323-24.

${ }^{30}$ Hash' hora, the black one, i.e., the black humour. Cf. note 18.

${ }^{30 a}$ M'zagim, constitutions. Lit. "mixtures."

${ }^{31}$ Haqadahat hat'midit, perpetual fever. De secr., pp. 51 a-b lists tertiana febris, quotidianae febres, continuae febres (this is our author's perpetual fever), and febres pestilentiales among the diseases which can be cured with the quinta essentia. To them are added in De med., p. 369, the following types of fevers: quartanae (see note 29), acutae, pestiferae, sanguinaea, cholericae, phlegmaticae, melancholiae, venales, aestivales, autumnales, and hyemales.

${ }^{32}$ Marqurial, Spanish mercurial, all good, mercury, mercurialis L. Cf. Hovorka-Kronfeld 1:69-70.

${ }^{33}$ Aduma w'appusha, red and putrefied (fever). Perhaps redwater fever. No such fever is mentioned in the Lullian treatises. See note 2.

${ }^{34}$ Hamis hanirpa, the cured (?) juice, or liquid. 


\section{An unknown Hebrew medical alchemist}

The sixteenth benefit is to cure the day and night fever which is generated by the putrefied white [humour]..$^{35}$ And since the white [humour] is cold and humid, take of our water with a little farfiyun ${ }^{36}$ and a little shawqu ${ }^{37}$ with other drugs which are antidotes of the white [humour], and let him drink it in the evening and in the morning, and it will help with the help of God.

The seventeenth benefit is to cure the epileptics of all kinds, and the acute fevers, and the sirsam. ${ }^{38} \mathrm{Know}$ that the acute fever is seated in the head. And since this fever is produced by the red, acute, and burned [humour], and also by burned blood, and at times by the burning of the three substances except the black one, therefore the physicians became confused in their cure. However, all these are cured by our medicine. Therefore one must take of our [folio 157v] essence with the essence of the gold and of the crystal and the blood, and put into them rose water and violas boraja lijunas, ${ }^{39}$ and therewith the patient will be cured with the help of God. ${ }^{39}$ For the healing of ringworm: pitch, one rotl; olive oil, one ounce; sesame oil, half an ounce; clarified butter, half an ounce; colophony, half and ounce; and the darur, ${ }^{39 b}$ peel it, roll it, burned [?]; and dog dirt, and every four [days?] cover its incision. And for him whose head trembles, let him take sesame oil, half an ounce; olive half, clarified butter half, mastic half, pitch half. Make an ointment and anoint the head, and every three days a hot bath, and between each plaster and plaster bathe. ${ }^{39 c}$ And if you want to cure the sirsam, take of the popilionointment,,$^{40}$ and choice vinegar, and ground garden rue, ${ }^{41} \mathrm{mix}$ all of it together with the essence of blood, ${ }^{42}$ and dip into this medicine pieces of linen cloth, and put them on the brain of the patient and on his nostrils, and thereby he will be cured, with the help of God. And know that this thing helps to cure the epileptics and all kinds of insanity.

The eighteenth benefit is to heal the pestilential fevers, that is to say, epidemic. If one is in the habit of using it at such times, with the help of God he will be saved from the pestilence, and the patients will be cured with the help of God by the essence of the blood, half of this and half of that with the roots of oxtongue ${ }^{43}$ and the vinegar herb which is called ${ }^{44}$ agritas $y$ si se paliare el ribas o el jarope de el es munju mejor, ${ }^{44}$ and a little of suqutri aloe ${ }^{45}$ and a little firfion ${ }^{46}$ and gira

\footnotetext{
${ }^{35}$ Hal'vana ham' uppeshet, the white putrefied (fever), i.e., fever caused by the putrefied white humour or phlegm.

${ }^{36} \mathrm{Cf}$. note 13.

${ }^{37} \mathrm{Cf}$. note 14.

38 Sirsam, Arabic sirsām, which, according to Zamakhshari's Lexicon Arabico-Persicum, means fever with headache and inflammation of the palate.

39 Violas, boraja, lijunas. Viola is violet; boraja is the Spanish borraja, borago L.; lijuna is possibly the logania. On viola cf. Muntner, Poisons, p. 97; Hovorka-Kronfeld 1:403, 431-32.

$39 \mathrm{a}-39 \mathrm{c}$ The paragraph between these two numbers is inserted as a box into the top right corner of folio $157 \mathrm{~b}$ of the MS. It is in Arabic, written in a different hand, in large Hebrew characters.

${ }^{39 b}$ Darur, could be the author's transliteration of Arabic darūr, meaning overflow or abundance, or of dharūr, powder, or an unusual form (plural?) of dhurra, a variety of sorghum. Perhaps also darū = mastic (Dubler III 55).

${ }^{*} M$ 'snilhat popilion, popilion ointment. Popilion is the modern Spanish populeon, a popular ointment prepared with pigs' butter, poppy leaves, belladonna, etc., and used as a sedative. Its principal base consists of the first shoots of black poplar trees, cf. Diccionario s.v. On the papilionaceae in folk-medicine, cf. Hovorka-Kronfeld 1:350.

${ }^{41}$ Roda ganit, garden rue, the ruta domestica. Cf. De secr. pp. 19a, 38a. Cf. Hovorka-Kronfeld 1:171, 356-58; Patai, pp. 347, 372.

${ }^{42}$ Mahut hadam, essence of blood. Cf. De Med., pp. 341-42 which describes in detail how to produce essence out of human blood.

${ }^{43}$ L'shon hashor. In other medieval Hebrew medical sources, also in Aramaic, l'shon tora or lishna tora, in Arabic lisān al-thawr. All these terms are the literal translation of the Greek buglosson, Latin lingua bovis, the Picris echoides L., borage. Cf. Lőw 1:295, 299; 4:133, 169, 170, 481; Siggel, p. 65; Patai, p. 346.

44 The sentence between these two numbers is in Spanish in Hebrew characters, which translates as "the vinegar herb which is called agritas, and if it is diluted with currant or with the syrup of it, it is much better." Agritas is the Spanish agrito, Berberis vulgaris L., cf. Diccionario, s.v. Ribas is the Spanish ribes, currant, from the Arabic ribas, a kind of sorrel. Jarope in Spanish is syrup. Cf. Meyerhof, p. 175, no. 350.

4s Sabar suqutri, from the Arabic sabr suqutri, Socotrine aloe, aloe socotrina or succotrina, the resinous
} 


\section{Raphael Patai}

pigra $^{47}$ and essential lilio ${ }^{47}$ root, mixed all this also with the essence of the gold and the crystal with a little qapili Venerises and hyssop, and he should do this regularly three times a day so that they should purge him of the empty substances, and he should use all the medicines which are antidotes to the poisonousness of the pestilence, and especially calf's stomach, ${ }^{49}$ and these mixed with aforementioned essence so that its effectiveness should be stronger and more apparent, with the help of God.

The nineteenth benefit is to cure the disease of spasms..$^{50}$ The physicians are in agreement that the fever is a good sign in this disease, and the experimenters ${ }^{50 a}$ said that if all the joints of the limbs are anointed with the juice of the herb called flamula, ${ }^{31}$ which is a herb that grows in the ashes and its leaves are similar to the leaves of the celery, and its flower is green, if they smear him many times with its juice, the spasm will be cured, and therefore there is nothing as good for this as our essence, for this will make him completely healthy, with the will of the Creator, and God is the True Physician.

And I shall now reveal to you other hidden secrets which remained hidden from the eyes of the physicians who preceded us.

Take of the herb called agrimonia, ${ }^{52}$ rue, fox-testicles ${ }^{53}$ with their roots, selidonia, sugar, ${ }^{54}$ and let them be pounded and put into the vessel of the alembic, on a gentle fire. And the water which ascends from it has wonderful properties, for there is no pain in the eye, even the strongest, which does not become cured by it. And it helps, if imbibed, to save from all kinds of deadly poisons, and it cleans the stomach and strengthens it, and it helps against all kinds of dropsyss which come from the cold, and it cures the Persian fire ${ }^{56}$ in three days if they dip into it chaff of hemp and put it on the afflicted place. It also is utterly effective against the illness of cancer if it is imbibed with the tzabars' and it should be put on the afflicted place as mentioned above, and changed three times a day.

Take pinpinellass-seed, and mustard seed, and perisils9-seed, and celery-seed, and clove, and matztaki, ${ }^{60}$ and equal part of each, and they should be pounded well, and kneaded with the blood of a he-goat and mixed with strong vinegar, and put into the recentor ${ }^{11}$ for three days, and

juice of the aloe from the island of Socotra, still sold under this name in the Cairo bazaar as a drastic and emmenagogue, cf. Meyerhof, p. 158, no. 318.

${ }^{46}$ See note 13.

${ }^{47}$ Gira pigra, from the Spanish gerapliega, hierapicra, a cathartic powder made of aloes and canella bark, cf. Muntner, Asthma, p. 139; idem, Poisons, p. 143.

${ }_{47 \mathrm{a}}$ Lilio, Latin lilium, lily.

"Qapili veneris, Venus hair, Adiantum capillus Veneris $L$.

"Qevat ha' egel, calf's stomach. I am unable to identify this disease.

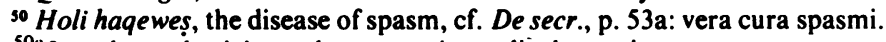

${ }^{50}$ a I.e., those physicians who engage in medical experiments.

s1 Flamula, cf. De secr., pp. 37b, 53a.

52 Agramonia, agrimony, cockle-bur. Cf. Hovorka-Kronfeld 1:120, 328.

${ }^{33}$ Eshkhe hashu'al, fox testicles. In other medieval Hebrew medical sources also called fox eggs. According to Löw 1:27, 652;2:296, it is the kynos orchis, a member of the orchidaceae family. According to Ben Yehuda, s.v. eshekh, it is the Satyrum album.

s4 Asukar, from the Spanish azucar, sugar.

${ }^{3 s}$ Shiqquy, dropsy. Cf. Ben Yehuda, s.v.

so Ha'esh haparsi, translation of Spanish Fuego Persico, Persian fire, an alternative term for Herpes zona, a cutaneous eruption. Cf. Molinar, s.v.

${ }^{37}$ Cf. note 45.

ss Pinpinela, Spanish pimpinela, burnet, a rosaceous plant. Cf. Hovorka-Kronfeld 1:32, 66; 2:312.

s9 Perisil, elsewhere spelled pirosil, Spanish peresil, parsley. Cf. Hovorka-Kronfeld 1:33, 170, 349; Patai, p. 372.

${ }^{\infty}$ Mastaki, Arabic mastaka, mastic. The reference probably is to the mastic thistle, Carlina gummifera. Cf. Siggel, p. 68; Meyerhof, p. 115, no. 232.

61 Resentor, an alchemical vessel. Cf. Testi, p. 153: restentorio, a vessel for collecting the product of distillation. 


\section{An unknown Hebrew medical alchemist}

then it should be distilled. This water is effective in breaking up kidney and bladder stones, if it is drunk on an empty stomach, and it cures the scabies ${ }^{62}$ if the head is washed with it, and it helps all kinds of boils if they are washed with it, and if they drink it twice it helps the parilisia, ${ }^{63}$ and it helps epilepsy if it is drunk evening and morning.

Take chicks of golondrinos ${ }^{64}$ and burn them, and pulverize them and mix them with qastorio, ${ }^{65}$ that is to say qashni, ${ }^{66}$ and put them into strong vinegar, and put it into a distilling vessel, and this water has many virtues. One is that if they drink it on an empty stomach they cure epilepsy completely if the patient drinks it for forty consecutive days, and it strengthens the brains, and clears the mind, and cleans the stomach and the chest, and softens the nerves and removes the ...67 from them, and strengthens the nature, [folio 158r] and helps those who have a cold. And if hyssop is cooked in this water it will help the rheum which comes from the cold, and it will cure all kinds of fevers. But beware lest you give it to a pregnant woman, for she would instantly miscarry. And it helps cold head ache, and [those who take it] will sleep comfortably. And it strengthen digestion and softens the belly and it makes the urine flow, and it causes the hair to fall out and it will not grow again.

Take hyssop and $a^{2}$ hal ${ }^{6 s}$ and akheronto $^{69}$ in equal parts in the distilling vessel, and the water which will come out will cure all kinds of head aches which come from cold, and all old fevers, and will cause the menses to flow. But the woman should not be pregnant for at times it [the menstruation] is kept back because of pregnancy and the woman will be weak. It also helps all kinds of diarrhoea, and it kills the worms which are born in the body if it is drunk on an empty stomach, and it cleans the stomach of all decayed substances, and if it is mixed with qastorio it will cure all kinds of falij. ${ }^{70}$

Take a bat and burn it and pound it with sulphur and mix it with the juice of selidonian and put it in a vessel up to six days, and then distil it, and this water has many uses. One: If any black hair is washed in it, it will turn white. Two: If you mix it with $t z a b a r^{72}$ and wax, and smear with it the pain of gout, ${ }^{73}$ it will cure it, and it will cure the kind of cancer which grows on the face, which is called noli me tangere, ${ }^{74}$ that is to say, touch me not, if it is smeared over it, and it will cure the scabies's by smearing.

Take pirosil ${ }^{76}$ and pound it and distil it and it will help to expel all kinds of winds and bloatings from the body, and will strengthen the digestion, and if they drink it with canelan it will

62 Neteq, scab, scabies. According to Ben Yehuda, s.v., a skin disease, perhaps tinea tonsurans, or herpes tonsurans.

${ }^{63}$ See note 11, and De secr., p. 46a, on the cure of paralysis.

64 Golondrinos, Spanish golondrinos, swallow, hirundo L.

6s Qastorio, Spanish castoreo, from the Greek kastorion, Latin castoreum. A strong-smelling oily substance obtained from the sexual glands of the beaver, used as a stimulant in medicine, and in making perfumes. Cf. De secr., p. 19a.

"6 Qashni, from the Arabic qashni, galbanum, a bitter, bad-smelling Asiatic gum resin used in medicine. Our author is in error in identifying castoreum with galbanum.

${ }^{67}$ Word illegible.

68 Avbal, Arabic abhal or abhul, savin, Juniperus sabina, a Eurasian evergreen with small berries. Its bitter, acrid tops were used in medicine for gout and amenorrhoea, and as an abortifacient. Cf. Siggel, p. I1; Meyerhof, p. 14, no. 22.

${ }_{69}$ Akheronto, perhaps from the Spanish agerato, sweet milfoil or maudlin, Achilles ageratum.

${ }^{10}$ Falij, Arabic fälij, half paralysis, hemiplegia. Cf. Muntner, Asthma, p. 137.

$"$ See note 7.

12 See note 45

${ }^{73}$ Niqras, Hebrew for gout. Ben Yehuda, s.v., lists several medicines for gout from medieval Hebrew medical authors. According to Muntner, Asthma, p. 114, niqras is podagra.

"Nolimitanjero, i.e., noli me tangere, touch me not. This was the name of several skin diseases characterized by ulcers. In the Spanish usage it means a malignant ulcer on the face or the nose.

75 See note 62 .

${ }^{76}$ See note 58 .

"Qanila, Spanish canela, cinnamon. The inner bark of certain tropical trees, still used as a spice and a tonic. Cf. Patai, p. 348. 


\section{Raphael Patai}

cure coughing and clean the chest. And if you distil also the artemisa ${ }^{78}$ and the polio, ${ }^{79}$ and mix them together with the water of the perisil, ${ }^{20}$ it will help more for all the aforementioned things.

Take white papaver'seed and pound it fine and mix it with the aforementioned water, and it will help the chest and the cough very much, and if qastorio 82 is mixed into it, it will help the falij..3

Take salviaes and polioss and pound them and distil them, and the water which comes up will warm the bodies which have caught cold, and will strengthen the head and the limbs, and improve the tonic, ${ }^{86}$ and will cure all kinds of boils, and produce good blood. And if one drinks of this water three times a day, up to forty days, it will cure all kinds of old diseases. And I call your attention to a great secret: if one takes the aforementioned water and puts it into the distilling vessel a second time and mixes with it the water of al butm, ${ }^{87}$ that is to say the fruit which is called hub al khadhra, ${ }^{\text {s8 }}$ distilled in the distilling vessel and with qastorio, it will cure all kinds of diseases which are born in the body, whether in its interior or on its exterior. This medicine was invented by a great sage, and many old diseases came upon him, and he saw this in his dream, and made it, and was cured, and he put it in writing so as to help many people. And it helps internal [diseases] by drinking, and external [diseases] by way of a plaster with chaff of qanavos (hemp)." And we have tried this medicine many times, and all those who take of the aforementioned mixture will be saved from leprosy and from perselia ${ }^{90}$ and from bad diseases which have no cure.

And now I shall tell you the manner of preparing the aforementioned water of al butm. Take one pound of tarmantina," half a pound of honey of which the froth has been removed, one pound of aqua vita. ${ }^{92}$ very fine Indian 'and, ${ }^{93}$ trandal, ${ }^{94}$ in equal parts. Arab tzamg, ${ }^{95}$ juz bawwa," kholanjan"7-root, kababa," reed, matztaki, ${ }^{99}$ quaranfal, ${ }^{100}$ sanbal, ${ }^{101}$ of each three drachms. They must be pounded well and put into the distilling vessel which is made of glass, and it must be well covered, and put on a gentle fire. And the first water which will come up will be pure, and receive it in a vessel while it comes out pure, and then it will come out like the appearance of fire, red and bright, receive it in another vessel. And increase the fire by a little, and when you see that the head of the distilling vessel is black and the water is coming out thick

13 Artimisa, Spanish artemisa, mugwort or wormwood. Cf. Hovorka-Kronfeld 1:104-5.

"Polio, from the Latin polium, or polion, perhaps the poley-germander. Cf. De secr., pp. 18a, 36a, 37b.

${ }^{20}$ See note 59.

21 Papaver, Spanish papaver, poppy. Cf. Hovorka-Kronfeld 1:235, 209-11.

2 See note 65 .

${ }^{23}$ See note 70 .

"Salvia, Spanish salvia, sage, a plant of the mint family. Cf. Hovorka-Kronfeld 1:171, 370-71; Patai, pp. 344, 346.

is See note 79.

"Approximate quotation from Prov. 17:22 which reads: "A merry heart improves the tonic."

"Al butm, Arabic al-butm, terebinth. "Water of the terebinth" is the turpentine. See note 91. Also called mastaka, mastic, see note 60 . Cf. Meyerhof, p. 36, no. 66.

i Hub al kasra, Arabic hubbat al-khadrä, fruit of the terebinth.

"Q Qanavos, hemp, a Mishnaic term, from the Greek kannabos or kannabis.

0 Perselia, probably a misspelling of perlesia, see note II.

91 Tarmintina, Spanish trementina, turpentine. Cf. Hovorka-Kronfeld 1:172; 2:29, 75.

92 Aqwa wita, Latin aqua vitae. In alchemy it usually means alcohol.

93 'And hindi, Indian 'and. I am unable to identify 'and.

94 Sandal, Arabic sandal, sandalwood. Spanish sándalo.

9s Semeg. A rabic samgh, gum. "Arab șamgh" is the gum Arabic, șamgh al-butm is the resin of the terebinth, cf. Mayerhof, p. 159, no. 320.

" Juz bawa, Arabic jūz bawwā, nutmeg.

"Kolanjān, Arabic khalanjān, Alpinia galanga or Maranta galanga. Cf. De secr., p. 19a.

" Kababa, Arabic kubāba or kabbāba, cubeb, Piper cubeba Tr. Cf. De secr., pp. 34a, 36a; Siggel, p. 62; Meyerhof, p. 96, no. 194.

9 See note 60.

100 Qaranfal, Arabic qaranful, cloves. Cf. Patai, p. 348.

101 Sanbal, Arabic sunbul, nard. Cf. Löw 3:62, 395; Muntner, Poisons, p. 108; Meyerhof, p. 129, no. 265. 


\section{An unknown Hebrew medical alchemist}

like honey, remove the second vessel and put another vessel, and increase the fire more, and do this until nothing more comes out. And know that these three are hot, to wit, the second is hotter than the first, and the third is hotter than the second. And know that the first is called "the mother of medicine", and the second "the substance of medicine", and the third "the complete medicine". The first, if it is taken lukewarm with wine will strengthen the stomach and expel from it the white [humour] which is closed in, and it arouses the desire to eat, and preserves the heart so that no evil vapour should go into it. And I tried this often. And if a thin piece of linen is dipped into it and put into the nostrils with the little finger when going to sleep, it will be very helpful against all kinds of drips. And it will improve the odour of the mouth and of the nostrils if drunk in the evening and in the morning. And it whitens the teeth if one gargles with it, and removes all aches from them. And if a piece of linen is soaked in it and then put on the face, it cures the redness of the face which is called barosnat. ${ }^{102}$ And it cures the heaviness of the tongue by drinking [it] and gargling. And if a piece of linen is soaked in it and then is put on haemorrhoids, it will cure them, and it will also cure deafness if cotton-wool is soaked in it and put into the ear.

Now I shall reveal to you the secret of the other two drops. They are good for cancer of the face which is called nujmi of Tangier, ${ }^{103}$ which was mentioned above, ${ }^{104}$ and for pain of the hips and the kidneys and the neck and the throat, if a cloth soaked in them is placed on the sore spots. And they are good for him who has fallen down from a high place, or was smitten by $\ldots,{ }^{105}$ or broke a bone, if he is bandaged with them, and they drive off all kinds of poisonous creeping [folio 158v] things. This is the rule: they are good for all diseases and all wounds, and all afflictions. And the third drop even more so.

Take the herb marqurial, ${ }^{106}$ and qandero-sugar ${ }^{107}$ in equal parts and pound them together and put them in the distilling vessel, and let them stand there ten days, then distil them as [you did with] the drops of water which were mentioned before, and if the third is put into a clean vessel it will shine at night like a candle. The third water is like oil. If a man or a woman anoints his face with it, it will cleanse it and beautify it, and if he drinks of this water every morning, even if he be a hundred years old, his youth will return to him as if he were twenty, and likewise all his limbs will shine brightly like [those of] a youth, and neither in his face nor in his body will any wrinkles be left at all. And if the epileptic drinks of it for forty days, he will be saved from his disease, and if qastorio ${ }^{108}$ is mixed into it, it will cure the crushed nerves and all the pains of the limbs of the body. And if it is put into the eyes which are afflicted by any disease whatsoever, it will cure them. And if pulverized gold and fine crystal and raubaibaro ${ }^{109}$ are mixed into it and pounded well and mixed, and the leprous drinks of it, he will be cured completely, on condition that he drink of it until the freshness of his face becomes beautiful.

Take rubia ${ }^{110}$-roots and pound them and cook them with olive oil and with perisil, ${ }^{111}$ in the amount of the roots, and it will cure the disease which is born in the bladder. And if you cook the rubia with parro, 112 and give it to drink to him who has a diarrhoea of blood, it will cure him.

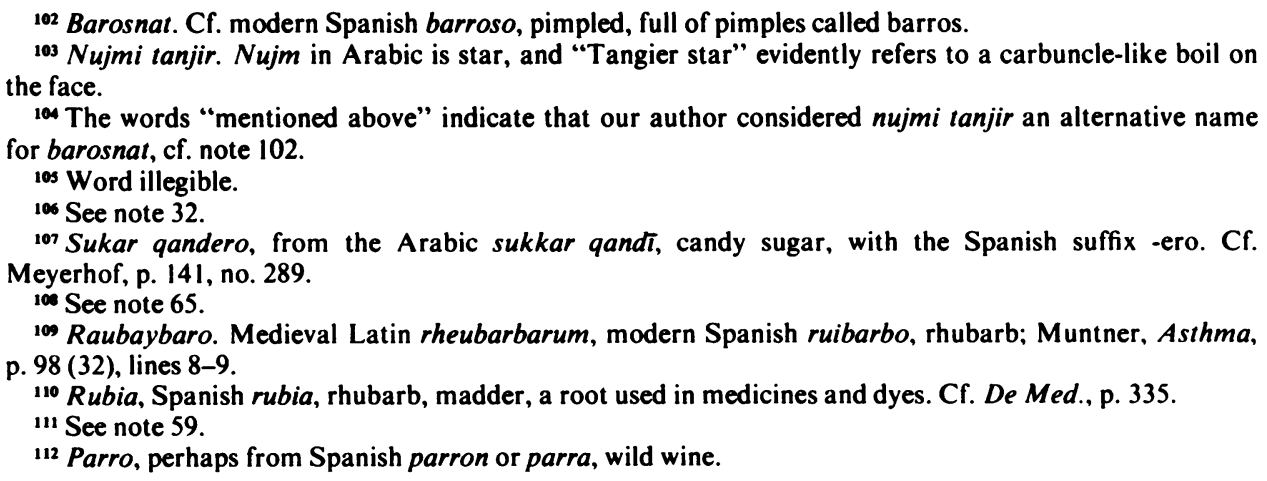




\section{Raphael Patai}

And if you cook it with bran and the gouty ${ }^{113}$ part is bandaged with it, it will cure it.

Take pinpinella seed and put it into good red wine for ten days, and then dry it and make oil of it, and it will be good for stones in the bladder. And also the juice of the pinpinella, if he drinks it, it will dissolve the stone and the patient will get it out in his urine in the form of sand.

Wondrous water which makes youth persist, and health remain, and this is its description: take good white wine, three pounds, uncooked honey of the beehive, one pound, and pulverized gold, and distil them, and let him drink of this morning and evening. This good medicine was sent by the king of Egypt to the king of Garnata [Granada] who was smitten with blindness which is called cataras, ${ }^{114}$ and he was cured by it. And this is its description: Take flowers of romero, ${ }^{115}$ with their leaves removed, and spread them on a rug so that the wind should blow on them, for two days, and then put them into a flagon, but do not fill it completely, and cover it with a lead tablet, and paste the bottom of the flagon with the clay of the philosophers, ${ }^{116}$ and put it in the garden into a hole full of very fine sand, and let it stand there ninety days of the days of the summer. And when the days are up, open the flagon and you will find the flower softened like honey, and distil it in a glass vessel, and keep the distillation for both drinking and putting it into the eyes, and it will help wonderfully, with the help of God.

Pills came from India, written in their language, and called in the language of Hind "pills of father and mother", for their benefit for a person is like the benefit of his father and mother, and this is their description: tirpola tirqota tangargayad ras $u$-bis gindek arhertal. And this is their explanation: tirpola ${ }^{117}$ three kinds of pepper, that is black and red and zanjabil, ${ }^{118}$ and because of its sharpness he calls it pepper. Tirqota ${ }^{119}$ - three kinds of mirabulanos, ${ }^{120}$ Babylonian, yellow, and amlaj. ${ }^{121}$ Tangargayad ${ }^{122}$ - atinkar. ${ }^{123}$ Ras $^{124}$ is quick-silver. ${ }^{125}$ Bis is bish. ${ }^{126}$ Gindek $^{127}$ is sulphur. Arhertal ${ }^{128}$ is zarnik. ${ }^{129}$ Equal parts should be pounded well and kneaded in

113 See note 73.

114 Qataras. Spanish catarata, cataract.

11 Romero, Spanish for rosemary, Rosemarius officinalis, an evergreen shrub of the mint family, with a warm, pungent, bitterish taste, used in cookery, perfumes, etc.

116 Tit hahokhma, clay of wisdom. The Hebrew term for the philosopher's clay which was an important alchemical substance to which all kinds of wonderful qualities were attributed.

${ }^{111}$ Tirpola. Sanskrit trịphala, having three fruits (namely the three Myrobalans, Terminalia Chebula, Terminalia Bellerica, and Phyllantus Emblica). Cf. Monier-Williams, p. 459; Alex Wayman, 'Notes on three Myrobalans', Phi Teta Annual, 1954-55, 5: 63-77 (publ. by the Oriental Languages Dept., University of California, Berkeley); Vd. Bhagwan Dash, 'The drug Terminalia Chebula in Ayurveda and Tibetan medical literature', Kailash: A Journal of Himalayan Studies 1976, 4: 5-20. Our author evidently mixed up the meaning of the two terms tirpola (triphala) and tirqota (trikatu, see note 119), and attached the explanation of the first to the second, and vice versa.

11 Zangavil, Arabic zanjabil, ginger or juniper berry.

11 Tirqoța, Sanskrit trikat $u$, the three spices (black and long pepper and dry ginger). Cf. MonierWilliams, p. 458. Three kinds of pepper (piper longum, album et nigrum) were part of the classical theriac, cf. Muntner, Asthma, p. 137.

120 Mirabulanes, Spanish mirabolano, myrobalan, a dried, astringent prune-like fruit of India. Lull, Secreta secretorum, Cologne, 1592, p. 26, lists Mirabolani conditi among medicines. Cf. Muntner, Asthma, p. 132, and note 117

121 Amlaj, Arabic, brownish. Our author refers to the Myrobalan amilegium, cf. Muntner, loc. cit.

122 Tangargayad, Sanskrit tankana, or tagara, or tankana-kshära, borax, cf. Monier-Williams, p. 429.

${ }^{123}$ Atinkar, Spanish atincar, borax. Cf. Ruland, p. 123: “Atincar, atinkar, id est borax de petra, baurach, boras, Burress von Felsen."

124 Ras, Sanskrit rása, quicksilver, cf. Monier-Williams, p. 869.

125 Zibaq or zaibaq, Persian and Arabic zi'baq, quicksilver. Cf. Meyerhof, p. 68, no. 139.

126 Bis, perhaps Sanskrit bisa, lotus plant, cf. Monier-Williams, p. 732. Bish, Arabic bish, aconite, monkshood, wolfsbane, a poisonous plant, Napellus Moysis, cf. Wahrmund, s.v.

${ }^{127}$ Gndek (thus vocalized in the MS), Sanskrit gandhaka, sulphur, cf. Monier-Williams, p. 345.

123 Arhertal, Sanskrit haritäla, yellow orpiment or sulphuret of arsenic, cf. Monier-Williams, p. 1291.

Hindi hartal, arsenic, cf. Bulcke, p. 40.

129 Zarnikh, Arabic zarnikh, arsenic. Cf. Siggel, p. 81 . 


\section{An unknown Hebrew medical alchemist}

the urine of goats and a decoction of apsantin, ${ }^{130}$ and let it dry in the shade, and then pounded a second time, up to seven times. And make [of them] pills like a pepper corn. Seven to be taken.

To release the menses strongly, take dar ${ }^{131}$ of pepper, one drachm; darsini, ${ }^{132}$ one drachm, juz $b a w w a^{133}$ one drachm, zangabil ${ }^{134}$ one drachm, za fran ${ }^{135}$ one drachm, pure incense one drachm, sulphur one drachm, misk ${ }^{136}$ a grain. They should be pulverized and kneaded in a little glue which is called jaris, ${ }^{137}$ and hukaro ${ }^{138}$ water, and let them make farazjat, ${ }^{139}$ and let the woman suffer ${ }^{140}$ one of them, and it will help with the help of God.

For pregnancy. The tooth of an elephant should be ground and mixed with theriak faruq, ${ }^{141}$ and let the woman eat one-third at the time of her menses, and one-third when she becomes purified, and one-third after her immersion, and she will conceive with the help of God.

${ }^{130}$ Apsantin, from the Greek apsinthion, wormwood. Cf. De secr. p. 36a; Muntner, Asthma, p. 131.

131 Dar, Arabic där, house, here meaning pod.

${ }^{132}$ Darsini, Arabic dă șin̄i, cinnamon bark, canella of China, Cinnamonum ceylanicum or aromaticum. Maimonides translates Hebrew, qinnamon, as dār șinin, cf. Muntner, Poisons, p. 109 (with additional references to other medieval Hebrew medical sources on cinnamon - dār sīnī); Siggel, p. 34; Meyerhof, p. 50, no. 95; Löw 2:106.

${ }^{133}$ See note 96.

${ }^{134}$ See note 118.

${ }^{133} \mathrm{Za}$ afran, Arabic za'farān, saffron. Cf. Meyerhof, p. 66, no. 135; Patai, pp. 347, 372.

${ }^{136}$ Mesekh, Arabic misk, musk. Cf. Siggel, p. 68; Patai, p. 347.

${ }_{137}^{13}$ Jaris, Arabic jaris, groat.

${ }^{138}$ Hukaro (reading uncertain). Jucaro is the Spanish term for the Terminalia hilariana and T. bucera, a tree whose fruit resembles the olive, cf. Molinar, s.v.

${ }^{139}$ Farazjat, Persian farzaja, suppository, clyster.

100 "Let the woman suffer...". The pónos, suffering, of the patient was part of the Hippocratic therapy.

${ }^{141}$ Teriaq faruq, Arabic tiryāq farüq, special (?) theriac. On various kinds of theriac cf. Muntner, Poisons, Index, s.v. teriaqim. Cf. also Hovorka-Kronfeld $1: 413 ; 2: 312$. 